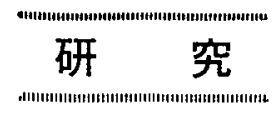

\title{
合金粉を用いた高強度 $\mathrm{P} / \mathrm{M}$ アルミニウム合金圧延板の 機械的性質に及ぼす製造時における脱ガス条件の影響*
}

\author{
鈴木 義和 ${ }^{* *}$ ，渡辺 侊尚 ${ }^{* *}$ ，土田 繁雄***
}

Yoshikazu Suzuki, Teruhisa Watanabe and Shigeo Tsuchida: Effects of Degassing Conditions in Fabrication Process on Mechanical Properties of High Strength P/M Aluminum Alloy Sheets Made from Alloy Powder.

The rolled sheets were made by $\mathrm{P} / \mathrm{M}$ method from 7091 alloy powder, and effects of degassing conditions on mechanical properties and microstructures were studied. The green compacts of the powder were encapsulated, and degassed at $653 \mathrm{~K} \sim 773 \mathrm{~K}$ for $0.3 \mathrm{~h} \sim 24 \mathrm{~h}$ in about $10^{-3} \mathrm{~Pa}$ vacuum. Following degassing, the compacts were hot pressed, hot rolled with $88 \%$ reduction, and then cold rolled with $67 \%$ reduction to obtain $1 \mathrm{~mm}$ thick sheets. Results obtained were as follows:

1) The degassing conditions considerably influenced the ultimate tensile strength (UTS) and the yield strength (YS) of the $\mathrm{P} / \mathrm{M}$ sheets in T6 temper. The $\mathrm{P} / \mathrm{M}$ sheets made through degassing at $733 \sim 773 \mathrm{~K}$ for $1 \mathrm{~h}$ or more showed the highest UTS of about $630 \mathrm{PMa}$.

2) The recrystallized grain size of the $\mathrm{P} / \mathrm{M}$ sheets in $\mathrm{T} 6$ temper was also influenced by the degassing conditions, and the relatively high degassing temperatures of $733 \sim 773 \mathrm{~K}$ led to fine grain size.

3) The P/M 7091 alloy sheets made through degassing at $733 \mathrm{k}$ for $1 \mathrm{~h}$ showed higher UTS than those of I/M 7091 and I/M 7075 alloy sheets in T6 temper, and the differences were $35 \mathrm{MPa}$ or more.

(Received February 27, 1989)

\section{I 緒 言}

近年，粉末诒金法 (P/M 法)により高強度アルミニウ ム合金を製造する研究が多く行われ，従来の溶融法すな わちインゴット冶金法 (I/M 法) に比べ優れた諸性質の 合金が得られている(2).乙れは，䠝霧法等の急冷凝固粉 は添加元素をより過飽和に固溶できるので3，乙れを原 料とする $\mathrm{P} / \mathrm{M}$ 法では, 合金組成の自由度が大きく均一 微細な合金組織が得られるためである・Al-Zn-Mg-Cu 系 合金についてあ P/M 法による合金開発が進められてお り, P/M 7091 合金 (典型組成 : Al-6.5 wt $\%$ Zn-2.5 wt $\%$ $\mathrm{Mg}-1.6 \mathrm{wt} \% \mathrm{Cu}-0.4 \mathrm{wt} \% \mathrm{Co}$ ) はその中で実用段階にあ る一例である゙。.これは I/M 法では用いられない高い濃 度の Co を添加した点を特徴とし, 高強度と良好な耐応 力雇食割れ性を兼ね備えた合金である.

一般に $\mathrm{P} / \mathrm{M}$ アルミニウム合金の製造には，材料のふ くれや熱間加工時の割れを防ぐために，Al 合金粉の表面 酸化物等加ら加熱中に生じるガス $\left(\mathrm{H}_{2} \mathrm{O}, \mathrm{H}_{2}\right.$ 等) を予め 除去する脱がス処理が必要となる. P/M 7091 合金関 して，ての脱ガス条件の影響を検討した研究は少なく， また同合金の圧延板を対象とした研究す少ない，そこで
本研究では P/M 7091 合金压延板を作製し, 脱ガス条件 が $\mathrm{P} / \mathrm{M}$ 圧延板の組織および機械的性質に及济す影響を 検討した。ささらに，この $\mathrm{P} / \mathrm{M}$ 压延板の諸性質を $\mathrm{I} / \mathrm{M}$ 合 金の圧延板と比較し，その特徵を明らかにするととを試 みた。

\section{II 実 験 方 法}

P/M 7091 合金延板の作製工程を Fig. 1 亿示す．原料 の7091合金粉（昭和電工滦）は窒素噴霧粉で，その組 成，粒度分布は Table 1,2 の通りである. ての合金粉を 金型で泠間成形し, $\phi 35 \times 52 \mathrm{~mm}$ の円柱形で圧粉密度が 約 $2.2 \mathrm{~g} / \mathrm{cm}^{3}$ (密度比約77\%) の圧粉体とした. 次に, この圧粉体を排気管付きのアルミニウム製の年に封入し， これを油拡散真空ポンプで排気しながら加熱し脱ガス処 理を行った. 脱ガス処理の加熱は真空度が約 $10^{-3} \mathrm{~Pa} に$ 達した時点で開始し, 昇温速度を $5 \mathrm{~K} / \mathrm{min}$ とした。 また， 脱ガス温度は Table 3 のように 653〜 773 K とし，保持

* 昭和 60 年11月本協会秋季大会にて一部発表, 平成元年 2 月 27 日受理.

** 早榣田大学材料技術究所, T169 新樎区西早䅧田2-8-26.

*** スカイアルミニウム(株)技術研究所, テ366 深谷市上野台 1351 . 


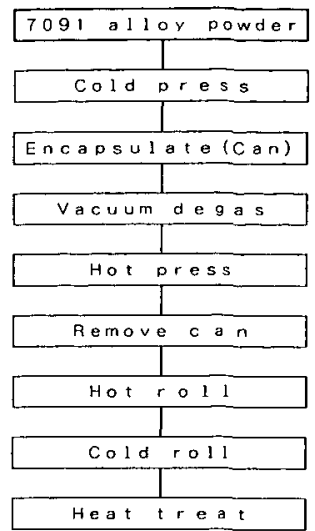

Fig. 1 Fabrication process of P/M 7091 alloy sheets.

Table 1 Chemical composition of 7091 alloy powder.

Wt $\%$

\begin{tabular}{c|c|c|c|c|c|c|c}
\hline $\mathrm{Zn}_{\mathrm{n}}$ & $\mathrm{Mg}$ & $\mathrm{Cu}$ & $\mathrm{Co}$ & $\mathrm{Fe}$ & $\mathrm{Si}$ & $\mathrm{Mn}$ & $\mathrm{Al}$ \\
\hline 6.49 & 2.59 & 1.58 & 0.390 & 0.138 & 0.107 & 0.003 & Bal. \\
\hline
\end{tabular}

Table 2 Particle size distribution of 7091 alloy powder.

\begin{tabular}{l|r|r|r|r|r|r|r}
\hline mesh & +100 & -100 & -145 & -200 & -280 & -350 & -400 \\
\hline Wtg6 & $\operatorname{Tr}$ & 9.2 & 19.2 & 21.4 & 17.0 & 12.6 & 20.5 \\
\hline
\end{tabular}

時間を $0.3 \sim 24 \mathrm{~h}$ とした. 脱ガス処理終了後は，排気管 を密封して缶でとホットプレス用金型に装入して王縮し た.ホットプレスの温度は脱ガス温度に対応して Table 3 のよう記設定し，加圧は約 $300 \mathrm{MPa}$ で $5 \mathrm{~min}$ 保持し た。このようにして得たビレットは外側について年の一 部老除去した後，ホットプレスの王縮方向之平行の方向 で压延を行った．熱間圧延前の予備加熱结, 大気雲团気 中で Table 3 のように脱ガスおよびホットプレスの温度 に対応して $633 \mathrm{~K}$ および $673 \mathrm{~K}$ の温度で $0.5 \mathrm{~h}$ 保持し た. 熱間圧延では，元厚 $25 \mathrm{~mm}$ の試料を 1 回の压延に つき 1 2 $\mathrm{mm}$ つ゚つ厚さを隇じ, 3〜 5 min の再加熱と仕 延を繰り返して $3 \mathrm{~mm}$ の板厚とした．乙の熱間圧延の圧 下率は88\%である，ての後さらに压下率 $67 \%$ 冷間压延 により $1 \mathrm{~mm}$ 厚の薄板試料とした，乙の薄板を大気焒に より $763 \mathrm{~K}, 0.5 \mathrm{~h}$ 保持の溶体化処理ののち水焼入れし， 約 $160 \mathrm{~h}$ の自然時効後, $393 \mathrm{~K}$ で $24 \mathrm{~h}$ の人工時効を行う
Table 3 Temperatures of degassing, hot pressing and hot rolling.

\begin{tabular}{c|c|c}
\hline Degassing & Hot pressing & Hot rolling \\
\hline $653 \mathrm{~K}$ & $643 \mathrm{~K}$ & $633 \mathrm{~K}$ \\
\hline $693 \mathrm{~K}$ & $683 \mathrm{~K}$ & \\
\hline $733 \mathrm{~K}$ & $723 \mathrm{~K}$ & $673 \mathrm{~K}$ \\
\hline $773 \mathrm{~K}$ & & \\
\hline
\end{tabular}

$\mathrm{T} 6$ 処理をほどこした。一方，比較用として実験的に I/M 7091合金圧延板を作製したが，これは銅製金型に鋯 造し $733 \mathrm{~K}$ で $15 \mathrm{~h}$ の均質化処理ののち，上記の $\mathrm{P} / \mathrm{M}$ 压延板とほぼ同条件で圧延したあのである．また，一般 に使われている I/M 7075 合金（典型組成： Al-5. $6 \mathrm{wt} \%$ $\mathrm{Zn}-2.5 \mathrm{wt} \% \mathrm{Mg}-1.6 \mathrm{wt} \% \mathrm{Cu}-0.23 \mathrm{wt} \% \mathrm{Cr})$ ， その熱 延板を入手し同様の圧延条件で比較用の試料とした。 こ れらの I/M 材の化学分析值を Table 4 亿示す. これら の陚料についてビッカース硬さ試験, 引張試験および顕 微鏡組織観察を行った。 引張試験は, JIS Z 2201 の13B 号試験片を用いて圧延方向に平行に引張った．压延板の 組轼は断面を Barker 法亏 で処理し光学顕微鏡で観察し た. また, STEM による組織観察も行った。

\section{III実験結果ならひに考察}

\section{III-1 P/M 7091 合金圧延板の機械的性質}

まず, Fig. 2 亿示すのは，脱ガス温度 $733 \mathrm{~K}, 1 \mathrm{~h}$ 保持之 して作製した P/M 7091合金圧延板の時効中の硬さおよ

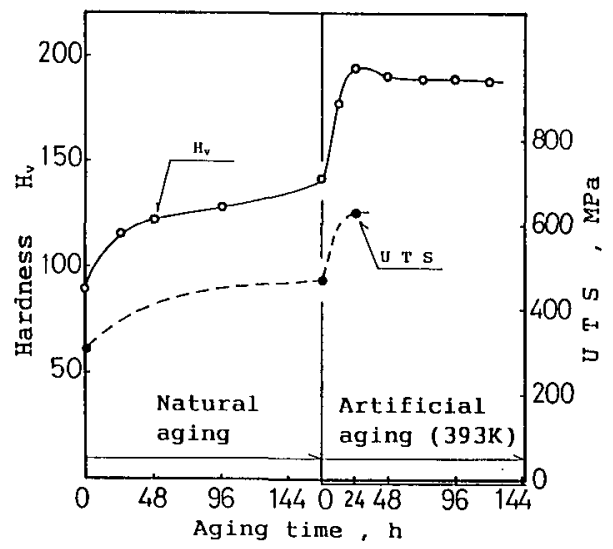

Fig. 2 Variations of Vickers hardness $\left\langle\mathrm{H}_{\mathrm{v}}\right\rangle_{\text {and }}$ ultimate tensile strength (UTS) with aging time at room temperature and $393 \mathrm{~K}$ for $\mathrm{P} / \mathrm{M} 7091$ alloy sheets made through degassing at $733 \mathrm{~K}$ for $1 \mathrm{~h}$.

Table 4 Chemical compositions of I/M 7091 and I/M 7075 alloy sheets.

wt\%

\begin{tabular}{c|c|c|c|c|c|c|c|c|c}
\hline Alloy & $\mathrm{Zn}$ & $\mathrm{Mg}$ & $\mathrm{Cu}$ & $\mathrm{Co}$ & $\mathrm{Fe}$ & $\mathrm{Si}$ & $\mathrm{Mn}$ & $\mathrm{Cr}$ & $\mathrm{Al}$ \\
\hline I/M 7091 & 6.87 & 2.68 & 1.59 & 0.368 & 0.114 & 0.05 & - & - & Bal. \\
I/M 7075 & 5.62 & 2.63 & 1.58 & - & 0.16 & 0.07 & 0.05 & 0.19 & Bal. \\
\hline
\end{tabular}




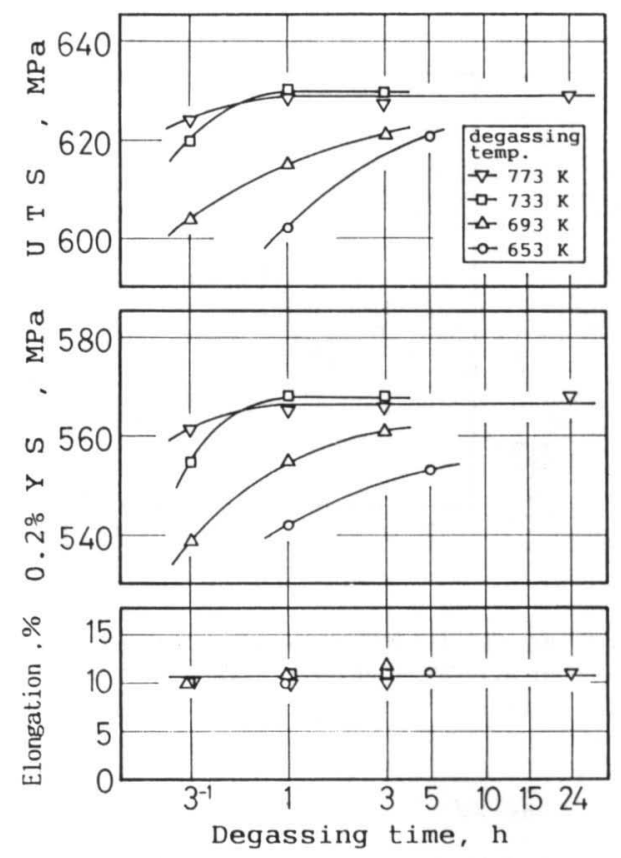

Fig. 3 Effect of degassing conditions on tensile properties of $\mathrm{P} / \mathrm{M} 7091$ alloy sheet in T6 temper.
び引張強さの変化である.こ扎よると $393 \mathrm{~K}$ での人工 時効を $24 \mathrm{~h}$ 行った時点で硬さがほぼ最高値となり,引張 強さは約 $630 \mathrm{MPa}$ となる. そこで以後全ての試料は, この条件で人工時効処理を行った. 本 $\mathrm{P} / \mathrm{M}$ 圧延板で時 効処理後に高い機械的強さを示すのは, 通常の $\mathrm{Al}-\mathrm{Zn}$ $\mathrm{Mg}-\mathrm{Cu}$ 系合金と同様に $\eta$ 相 $\left(\mathrm{MgZn}_{2}\right)$ 等の析出硬化によ る.

次に脱ガス処理の加熱条件を変えて作製した $\mathrm{P} / \mathrm{M}$ 圧 延板の $\mathrm{T} 6$ 処理後の引張試験結果を Fig. 3 亿示す. これ によると, 脱ガス温度 $733,773 \mathrm{~K}$ で $1 \mathrm{~h}$ 以上保持した場 合に引張強さが約 $630 \mathrm{MPa}$, 耐力が 565 570 MPa と最 あ高い值を示す. こ机に対し， $653 \mathrm{~K}$ では $1 \mathrm{~h}$ 保持で引 張強さ $600 \mathrm{MPa}$, 耐力が $540 \mathrm{MPa}$ 程度の低い值であり, $5 \mathrm{~h}$ 保持であ引張強さ $620 \mathrm{MPa}$, 耐力 $550 \mathrm{MPa}$ 程度であ る.一般に, 脱ガス処理はできるだけ低温, 短時間保持 で行い, 急冷合金粉の均一組織をそのまま保つ方が有利 と考えられるが1)，本実験では $733,773 \mathrm{~K}$ という比較 的高い脱ガス温度の方が良好な機械的強さを示した．ま た，伸びについては各条件の間で顕著な差は見られず, 10〜12\%の值であった.

III-2 P/M 7091 合金圧延板の顕微鏡組織

脱ガス条件を変えて作製した P/M 7091 合金圧延板の

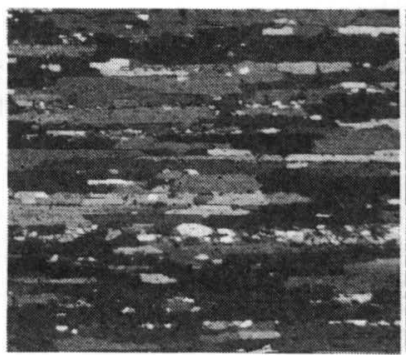

(a) $653 \mathrm{~K}, 1 \mathrm{~h}$

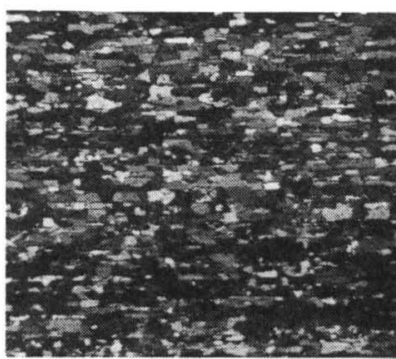

(d) $733 \mathrm{~K}, 1 \mathrm{~h}$

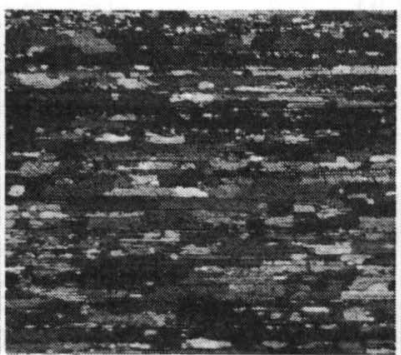

(b) $653 \mathrm{~K}, 5 \mathrm{~h}$

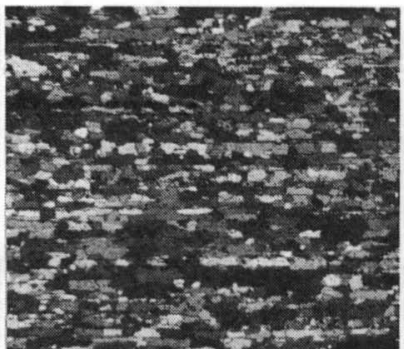

(e) $773 \mathrm{~K}, 1 \mathrm{~h}$



(c) $693 \mathrm{~K}, 1 \mathrm{~h}$

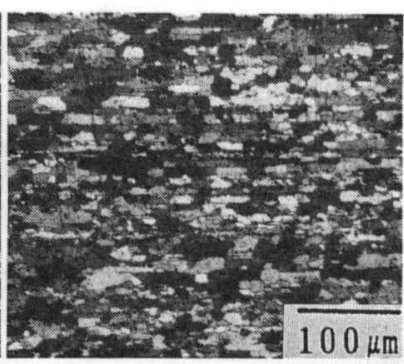

(f) $773 \mathrm{~K}, 24 \mathrm{~h}$

Photo. 1 Optical micrographs of P/M 7091 alloy sheets in T6 temper, which made through various degassing conditions.

L: longitudinal direction, ST: short transverse direction. 
Table 5 Grain size and yield strength (YS) of P/M 7091 alloy sheets.

\begin{tabular}{|c|c|c|c|c|c|c|c|}
\hline \multirow{2}{*}{ No. } & \multicolumn{2}{|c|}{ Degassing } & \multicolumn{3}{|c|}{$\begin{array}{c}\text { Grain size } \\
\mu \mathrm{m}\end{array}$} & \multirow{2}{*}{$\begin{array}{c}d^{-1 / 2} \\
\mu \mathrm{m}^{-1 / 2}\end{array}$} & \multirow{2}{*}{$\begin{array}{c}\text { YS } \\
\mathrm{MPa}\end{array}$} \\
\hline & $\underset{\mathrm{K}}{\mathrm{Temp}}$ & $\underset{\mathrm{h}}{\mathrm{Time}}$ & $d_{\mathrm{L}}$ & $d_{\mathrm{ST}}$ & $d$ & & \\
\hline 1 & 653 & 1 & 57.2 & 11.8 & 25.1 & 0.200 & 543 \\
\hline 2 & 653 & 5 & 34.9 & 8.9 & 17.7 & 0.238 & 553 \\
\hline 3 & 693 & $3^{-1}$ & 34.2 & 11.0 & 20.1 & 0.223 & 539 \\
\hline 4 & 693 & 1 & 32.0 & 8.9 & 17.2 & 0.241 & 555 \\
\hline 5 & 693 & 3 & 23.2 & 8.6 & 14.8 & 0.260 & 561 \\
\hline 6 & 733 & $3^{-1}$ & 22.0 & 8.9 & 14.8 & 0.260 & 555 \\
\hline 7 & 733 & 1 & 15.7 & 7.9 & 11.8 & 0.291 & 570 \\
\hline 8 & 733 & 3 & 16.2 & 8.1 & 12.2 & 0.287 & 570 \\
\hline 9 & 773 & $3^{-1}$ & 22.3 & 8.4 & 14.4 & 0.264 & 561 \\
\hline 10 & 773 & 1 & 20.2 & 8.3 & 13.7 & 0.270 & 565 \\
\hline 11 & 773 & 3 & 21.8 & 8.4 & 14.2 & 0.265 & 563 \\
\hline 12 & 773 & 24 & 15.9 & 8.2 & 12.1 & 0.287 & 572 \\
\hline
\end{tabular}

$d_{\mathrm{L}}$ : Grain size in longitudinal (L) direction. $d_{\mathrm{ST}}$ : Grain size in short transverse (ST) direction.

$d$ : Mean grain size calculated using equation (1).

光学顕微鏡による断面組織を Photo. 1 に示す. これより $\mathrm{T} 6$ 処理後の $\mathrm{P} / \mathrm{M}$ 圧延板の再結晶粒径が脱ガス条件に より大きく異なることがわかる. すなわち, 同じ $1 \mathrm{~h}$ 保 持であ脱ガス温度 $653 \mathrm{~K}$ の試料はかなり粗大な再結晶 粒で，これに比べ $733,773 \mathrm{~K}$ の試料では結晶粒は微細 である. また, 脱ガス温度が同じ $653 \mathrm{~K}$ では $5 \mathrm{~h}$ 保持の 試料の方が $1 \mathrm{~h}$ のあのより再結晶粒が小さい.さらに検 討するために熱処理した $\mathrm{P} / \mathrm{M}$ 圧延板の断面組織より圧 延方向（L方向）および板厚方向 (ST 方向) の 結晶粒 径 $d_{\mathrm{L}}, d_{\mathrm{ST}}$ を切断法で測定し次式 ${ }^{6)}$ より平均結晶粒径 $d$ を求めた。

$$
d=3\left(2 d_{\mathrm{L}}^{-1}+d_{\mathrm{ST}^{-1}}\right)^{-1}
$$

この結果を, 耐力の值ととあに示した Table 5 によると 結晶粒が微細な試料ほど耐力が高い傾向があり, 次のよ うに考えることができる.

一般に多結晶体の結晶粒径 $d$ と降伏強さ $\sigma$ の関係之 して, 以下に示す Hall-Petch の関係式 ${ }^{7}$ が知られている.

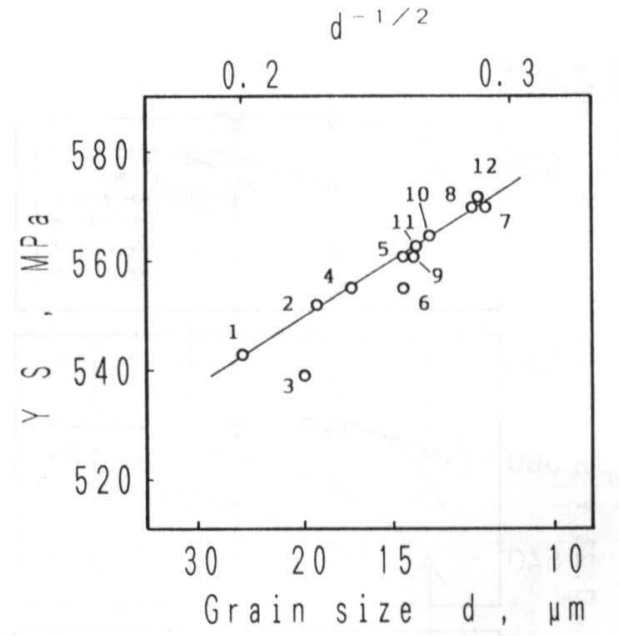

Fig. 4 Relation between mean grain size $(d)$ and yield strength (YS) of $\mathrm{P} / \mathrm{M} 7091$ alloy sheets in T6 temper.

$$
\sigma=\sigma_{0}+k d^{-1 / 2}
$$

ここで, $\sigma_{0}, k$ は定数である. 本 $\mathrm{P} / \mathrm{M}$ 圧延板について, $d^{-1 / 2}$ 之耐力の関係を図示すると Fig. 4 のように両者に 直線的関係が見られ，おおむね (2)式の関係が成り立っ ている. そこで前述の脱ガス条件による耐力の変化は, 主に結晶粒径の差に起因すると考えられる. ただし, 脱 ガスが不十分となる条件では局部的な気孔発生等の原因 で強さが低下する可能性あある. なお, 本 $\mathrm{P} / \mathrm{M}$ 材と類 似の組成を持つ7075合金においてあ T6 処理後に HallPetch の関係が成り立つとの報告あある ${ }^{8}$.

この $\mathrm{P} / \mathrm{M}$ 圧延板の結晶粒径の脱ガス条件による変化 は Co の挙動と関係づけて考察できる. $\mathrm{Al}$ 中の Co の平 衡固溶限は $0.02 \mathrm{wt} \%$ 以下 ${ }^{3}$ であるが, 7091 合金粉中の $0.4 \mathrm{wt} \%$ の Co は急冷凝固のため過飽和に固溶されてい る. この Co は後の加熱工程で $\mathrm{CO}_{2} \mathrm{Al}_{9}$ として析出する と考えられ, 脱ガス処理の温度と時間がこの析出に大き (影響を与えるとされている ${ }^{9)} \mathrm{I} / \mathrm{M}$ 法の $\mathrm{Al}-\mathrm{Zn}-\mathrm{Mg}-$

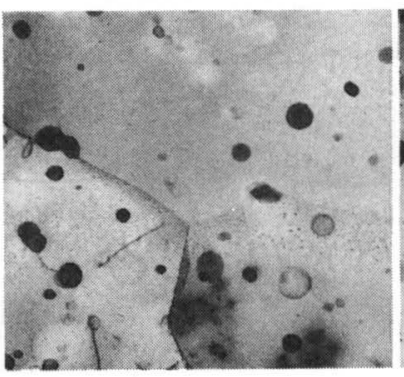

(a)

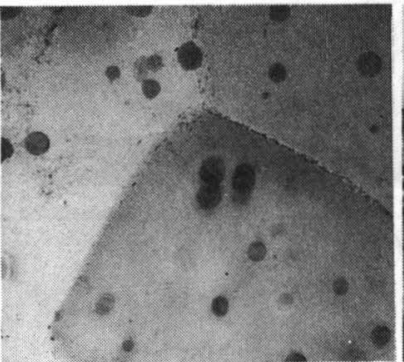

(b)

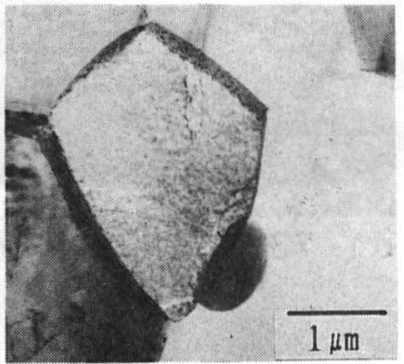

(c)

Photo. 2 TEM micrographs of P/M 7091 alloy sheets in T6 temper. Degassing condition: (a) $653 \mathrm{~K}, 1 \mathrm{~h}$. (b), (c) $733 \mathrm{~K}, 24 \mathrm{~h}$. 


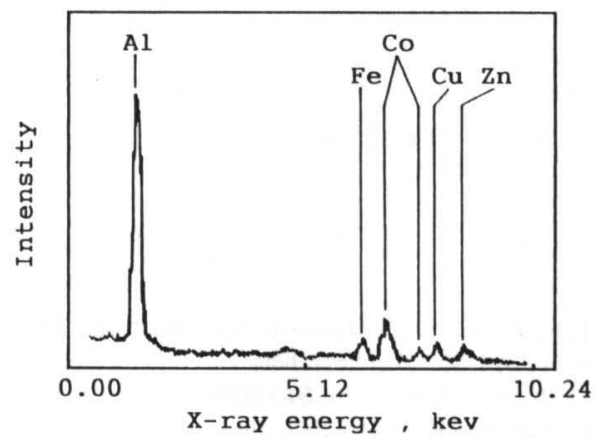

Fig. 5 EDX analysis of an intermetallic particle containing $\mathrm{Co}$ and $\mathrm{Fe}$ in the P/M 7091 alloy sheet in T6 temper which was made through degassing of $773 \mathrm{~K}, 24 \mathrm{~h}$.

$\mathrm{Cu}$ 系合金であ結晶粒微細化のため $\mathrm{Cr}, \mathrm{Mn}, \mathrm{Zr}$ 等の遷移 元素が少量添加され，これらは鋳造後の均質化処理中に 不溶性の金属間化合物として析出・分散して, 溶体化処 理時の再結晶または再結晶粒の粗大化を抑制する効果を 示す ${ }^{10)}$. そして, 析出物の量が多くて分散密度が高いほ どての効果は大になる．本 $\mathrm{P} / \mathrm{M}$ 圧延板でも析出した $\mathrm{Co}_{2} \mathrm{Al}_{9}$ の分散粒子が同様の働きをすると考元られ，比較 的に高い温度の脱ガス処理で $\mathrm{Co}_{2} \mathrm{Al}_{9}$ の析出が十分進む 場合に, $\mathrm{T} 6$ 処理後の $\mathrm{P} / \mathrm{M}$ 压延板の再結晶粒が微細にな ったと思われる.

次に, P/M 圧延板をSTEM で観察した結果をPhoto 2 亿示す. 付属の EDX で分析すると組織中の分散粒子 には Co を含むあのと含まないあのがある. 前者は比較 的に球形に近く $\mathrm{Co}_{2} \mathrm{Al}_{9}$ と考元られるが， Fig. 5 のよう にわずかの $\mathrm{Fe}$ 古有している. Coを含まない粒子は酸 化物 $\left(\mathrm{Al}_{2} \mathrm{O}_{3}, \mathrm{MgO}\right.$ 等) または $\eta$ 相 $\left(\mathrm{MgZn}_{2}\right)$ 等と考えら れる. 酸化物は合金粉の表面酸化皮膜か破碎されたもの で元の粉末粒界付近に多く存在すると思われるが，その 分布が再結晶粒径や機械的性質に影響するとの報告 ${ }^{11}$ 屯 あり，とれら分散粒子についてはさらに詳しい検討が必 要であろう.

\section{III-3 I/M 合金圧延板之の比較}

P/M 7091 合金压延板と I/M 7091 および 7075合金の T6 処理後の引張特性を比較したのが Fig. 6 である.こ 机よると両 $\mathrm{I} / \mathrm{M}$ 合金と屯に引張強さ $580 \mathrm{MPa}$ 以下 で, 耐力も $\mathrm{P} / \mathrm{M}$ 压延板よりはるかに低い。ただし, 伸 びに関しては I/M 7075合金が少し高い值を示した。

Photo. 3 に I/M 7091 おょよ゙゙7075合金圧延板の断面組 織を示す. Photo. 1 ととれらとを比較すると, P/M 7091 合金圧延板は脱ガス条件等を適切に選べば I/M 圧延板 よりも微細な再結晶粒となるととがわかる。I/M 7091 合金圧延板では再結晶粒が等方的に粗大となったが，こ 机は $\mathrm{Co}_{2} \mathrm{Al}_{9}$ 粒度が数 $\mu \mathrm{m}$ 以上之粗大で分散粒子数が少 ないので結晶粒微細化への効果を十分に果たさないため

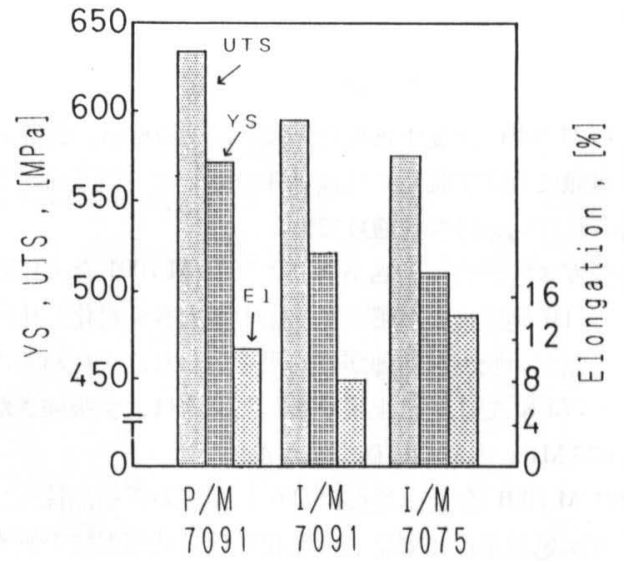

Fig. 6 Tensile properties of P/M 7091, I/M 7091 and $\mathrm{I} / \mathrm{M} 7075$ alloy sheets in $\mathrm{T} 6$ temper. The $\mathrm{P} / \mathrm{M}$ sheet was made through degassing at $733 \mathrm{~K}$ for $1 \mathrm{~h}$.
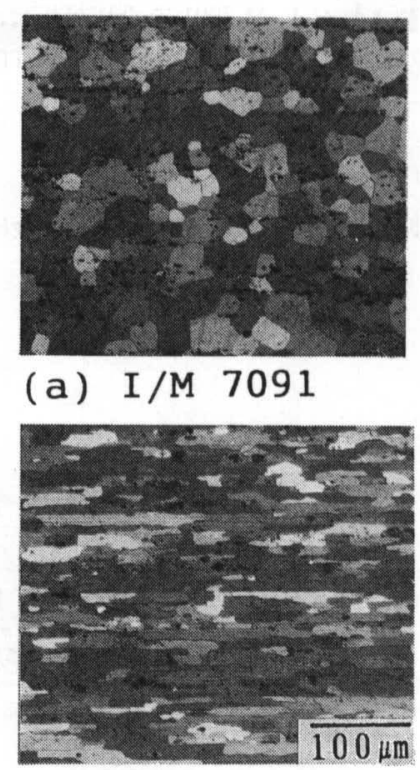

(b) I/M 7075 $\uparrow \mathrm{ST}$

$\overleftarrow{\mathrm{L}}$

Photo. 3 Optical micrographs of I/M 7091 and 7075 alloy sheets in T6 temper.

L: longitudinal direction.

ST: short transverse direction.

と考えられる. この結果により, $\mathrm{P} / \mathrm{M}$ 圧延板の結晶粒が 微細となるのは均一で密に分散した $\mathrm{Co}_{2} \mathrm{Al}_{9}$ 粒子の効果 によるということが間接的に裏付けられる.この $\mathrm{Co}_{2} \mathrm{Al}_{9}$ 粒子の分散状態の違いは, $\mathrm{P} / \mathrm{M}$ 圧延板では窒素噴霧法の 凝固冷却速度が $10^{3} \sim 10^{4} \mathrm{~K} / \mathrm{sec}$ と大きいため Co が過飽 和に固溶し脱ガス処理時等に $\mathrm{Co}_{2} \mathrm{Al}_{9}$ として析出するの に対し, 同組成の $\mathrm{I} / \mathrm{M}$ 圧延板では金型鋳造の凝固冷却 速度が $10 \mathrm{~K} / \mathrm{sec}$ 程度と小さいため粗大な $\mathrm{Co}_{2} \mathrm{Al}_{9}$ 粒子が 
鋳造時に晶出したためと考えられる。

$$
\mathrm{N} \text { 結 言 }
$$

P/M 7091 合金辰延板を作製し，その機械的性質およ び組織に及ばす脱ガス処理条件の影響について検討した。 得られた結果は次の通りである。

(1)脱ガス処理時の加熱条件により P/M 7091 合金王延板 の $\mathrm{T} 6$ 処理後の引張強さ, 酎力が大きく変化し比較的 高温での脱ガス処理か好結果を示した．すなわち，733 〜73 K で $1 \mathrm{~h}$ 以上脱ガスしたすのは，引張強さが約 $630 \mathrm{MPa}$ と最高の值を示した。

(2)P/M 7091 合金圧延板の T6 処理後の再結晶柆径は脱 ガス処理条件に対応して変化し比較的高温での脱ガス 処理で結晶粒が微紐になった。すなわち 733〜 773 K で脱ガスしたものは再結晶粒が 12〜14 $\mu \mathrm{m}$ と微細で， $653 \mathrm{~K}$ の試料は $25 \mu \mathrm{m}$ 以上と粗大になった。

(3)適切に作製された P/M 7091 合金圧延板は，I/M 7091 または I/M 7075 合金圧延板と比較して $\mathrm{T} 6$ 処理後の 引張強さで $35 \mathrm{MPa}$ 以上高い値を示した。

$$
\text { 謝辞 }
$$

本研究は昭和 $60 ， 61$ 年度科学研究費補助金によって行
われた．研究を進めるにあたり御助言を賜った早稲田大 学名栄教授 雄谷重夫博士および元スカイアルミニウム 渋常任顧問 松原邦晴氏，また協力をいただいた本学大 学院修士，[見]日本電気琍の玉置智氏亿感謝の意を表す 万。

1) J. R. Pickens: J. Materials Sci., 16 (1981), 1437.

2）武田：軽金属, 37 (1987), 639

3) H. Jones: Aluminum, 54 (1978), 274

4) E. Laernia, B. Poggiali, I. Servi, J. Clark, F. Katrak and N. Grant: Metal Powder Report, 41 (1986), 272.

5) L. J. Barker: Trans. AIME, 42 (1950), 347.

6) J. A. Wert, N. E. Paton, C. H. Hamilton and M. W. Mahoney: Met. Trans., 12A (1981), 1267.

7) N. J. Petch: J. Iron \& Steel Inst,, 173 (1953) 25.

8) J. A. Wert: Strength of Metals and Alloys, Vol. 1, Pergamon Press, Oxford, (1982) 339.

9) J. P. Lyle and W. S. Cebulak: Met. Trans. A, 6A (1975) 685

10）伊藤，江藤，宮城，荣野：軽金属，38 (1988) 819 .

11) Y-W. Kim and L. R. Bidwell: High-Strength Powder Metallurgy Aluminum Alloys, TMS-AIME (1982) 107.

\section{新入正会 員}

（平成元年10月16日現在）

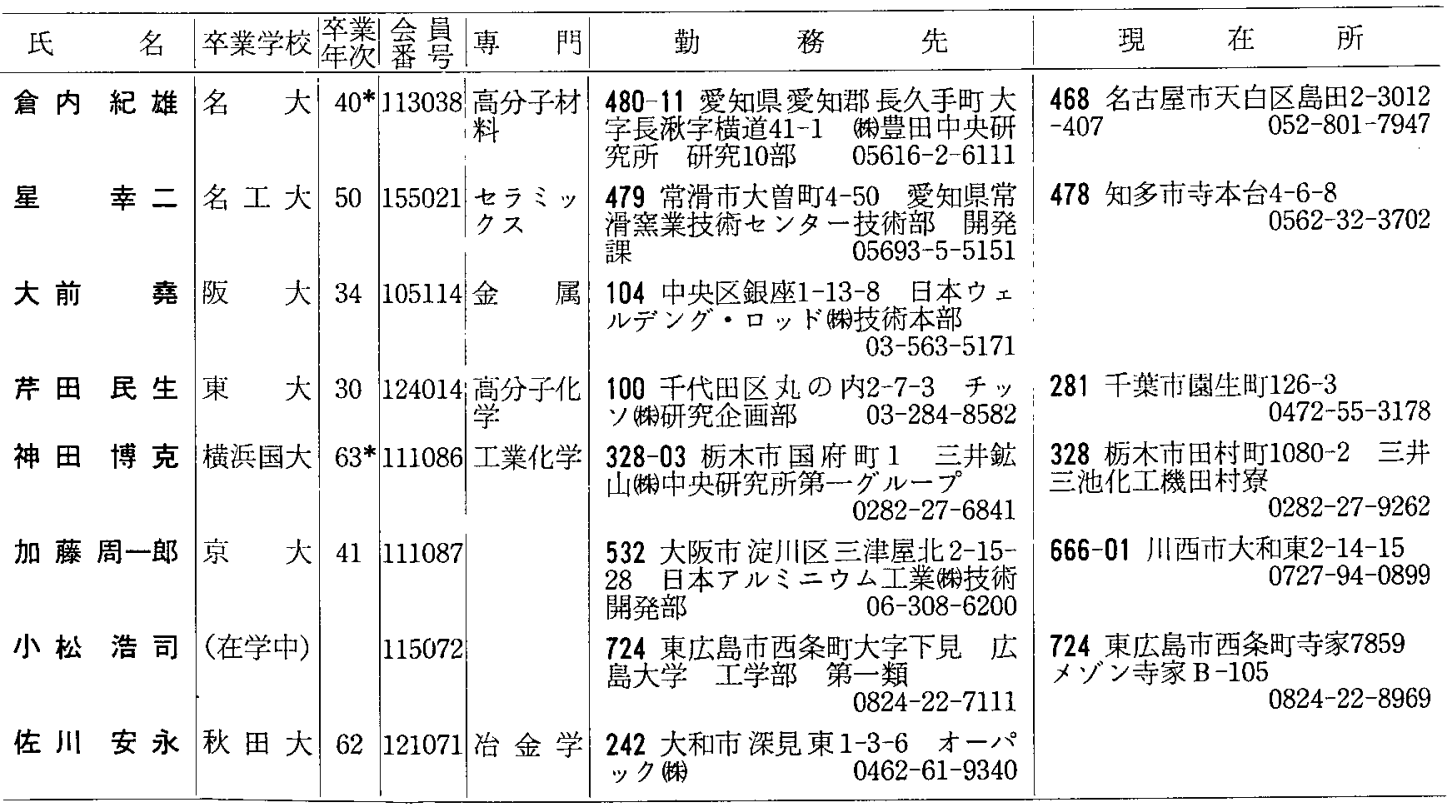

